\title{
ANALYSIS OF ADOPTION INTENTION TOWARDS ASYNCHRONOUS LEARNING ON CLOUD BASED SYSTEMS
}

\author{
Balaji R \\ Research Scholar, Faculty of Management, SRM Institute of Science and Technology, \\ Kattankulathur, Tamilnadu, India
}

Krishnan A.R

Professor, Faculty of Management, SRM Institute of Science and Technology, Kattankulathu, Tamilnadu, India

\begin{abstract}
The cloud technology has transformed the learning industry in a great manner. The entry barrier for starting a new organization has become thinner, therefore is higher potential for competition to the new entrants. There is a need for measuring the factors that motivate the leaner to adopt the online Learning platform in order to create a sustainable business in the Internet space. The study deals about identifying the predominant factor the online learning business owners in the cloud technology has to focus in order to maintain their competitive edge over others.
\end{abstract}

Key words: Asynchronous eLearning, Virtual education, Digital learning.

Cite this Article: Balaji R and Krishnan A.R, Analysis of Adoption Intention towards Asynchronous Learning on Cloud Based Systems, International Journal of Management, 11(9), 2020, pp. 947-952.

http://iaeme.com/Home/issue/IJM?Volume=11\&Issue=9

\section{INTRODUCTION}

The advent of the cloud based technology finds multiple applications especially in the education sector. The resources when it is available in the cloud can be shared in any location which helps the blended learning objective of the educational institutions. In order to provide an effective learning system for the learners in the online learning platforms it is inevitable to understand their requirements of the learning dimensions. There are multiple competitors in the online learning arena and sustainability is a biggest challenge for the learning platforms where successful completion rate and new enrolments remain critical. Therefore the dynamic requirements of the participants in the system time to time changes at par with the technical requirements as well. The study focuses on the basic aspects, which would create a positive sustainability in the learning platforms. 


\section{LITERATURE REVIEW}

The significance of understanding the user interaction with online learning portals has a higher input for the business models in the learning arena which has a continuous change in the preferences. The ease of setting up a business in the online learning models has become easy and therefore has reduced the competitive advantage of the first movers in many aspects. The advent of the digital marketing tools help to achieve the audience base rapidly and achieve the break even within a shorter period of time (Shalev-Shwartz, 2011). There is always a close competition between the distance learning programs and online learning programs. In many ways the cost of carrying out a online learning program is much lesser than the distance learning due to the lesser incremental cost components. The distance learning touch points are found to be lesser effective than the online mode(J. L. Moore, Dickson-Deane, \& Galyen, 2011). Self efficacy of the learners is found to have a key role in terms of successful conduct and completion of courses. Therefore the design of the course must be aligned to the needs and interactions of the learners to motivate the self efficacy aspect(Shen, Cho, Tsai, \& Marra, 2013). Flexibility of the online learning courses enhances the enrollment rates of the potential candidates in the online learning platforms.

The ease in which the learners access the courses and the utility of the course felt by the learners becomes factors dictating the success of the online courses(Sun, Tsai, Finger, Chen, $\&$ Yeh, 2008). The courses need to have customizable components for various user profiles especially in terms for new users and experienced users. The continuance intention of the learners in the online learning platforms have a significant impact for the sustainable businesses of online learning(Lin, 2011). The technical aspects of the e learning platforms has a higher impact towards the effectiveness of the learning activities by the users and it helps to provide uninterrupted services when the customer base scaling up(Liaw, 2008). The key aspects of the adult learners who contribute the maximum consumerism for the online learning platform is the immediate value, which can be added in their present job profile. This value addition to their jobs is successful only when they learn the key concepts experientially(Ghirardini, 2011). The system accessibility in the online learning platforms is a key dominating variable towards the intention to adopt the online learning systems(Park, 2009). The content of the online learning courses have to be updated periodically in order to promote the sustainability of the online learning platforms(Tavangarian, Leypold, Nölting, Röser, \& Voigt, 2004).

The assessments of the courses in the online learning platform has to be testing the fundamental knowledge gained through the online learning courses. Nowadays the peer grading systems are in place in order to have the collaborative learning among the participants in the online learning systems(Koohang, Riley, Smith, \& Schreurs, 2009). The counseling and support for the learners in the online learning systems motivate the students to complete the courses within the time frame specified(Paechter, Maier, \& Macher, 2010). There must be a focus group interaction before designing the online course in order to collect their requirements of the users for the effective design of the course(D. R. Moore, 2006). The advent of gamification has improved the practical learning aspects of the online learning platforms in understanding complex concepts taught by the experts(Urh, Vukovic, Jereb, \& Pintar, 2015). The online learning systems have supplemented the regular academic courses in multiple aspects which creates a better learning focus towards the nuances and innovative aspects in the physical interactive sessions(Arkorful\& Abaidoo, 2015). The online learning platforms provide the inclusiveness in education which reaches people from all walks of life in providing empowerment apart from the differences(Sangrà, Vlachopoulos, \& Cabrera, 2012). 


\section{OBJECTIVES OF THE STUDY}

To analyze the factors affecting the intention to use cloud based learning platforms by the learners.

To understand the relatedness of demographic variables towards the cloud based learning platforms

\section{RESEARCH METHODOLOGY}

The primary data is collected using a survey questionnaire and the sampling method adopted is the Judgment sampling wherein the respondents who have enrolled with at least one cloud based learning system have been taken for the study. The sample size is estimated to be 523 . The data extracted is analyzed using the Statistical package for social sciences and Smart PLS 3.0 which used the Partial Least Square technique for Structural Equation Modeling.

\section{ANALYSIS AND INTERPRETATION}

The constructs used for the study in order to find the intention to adopt cloud based learning systems are as follows

Intrinsic Motivation - The motivation that is based of the internal psychological factors of the learner

Extrinsic motivation - The motivational factors that the learner derives from the outside environment.

Availability - The means to access the online learning platforms

Collaboration - the collective interaction among the learners

Notification - The reminders and notification the student gets towards the completion of the course.

\section{Reliability}

Table 1

\begin{tabular}{|l|c|}
\hline \multicolumn{1}{|c|}{ Constructs } & Cronbach Alpha \\
\hline Intrinsic Motivation & .72 \\
\hline Extrinsic Motivation & .83 \\
\hline Availability & .88 \\
\hline Collaboration & .91 \\
\hline Notification & .84 \\
\hline Adoption Intention towards & .71 \\
Cloudbased Learning systems & \\
\hline
\end{tabular}

From the Above table, it is found that the cronbach value for all the constructs are above .7 which exhibits the reliability of the constructs taken in the study. The instrument will give consistent results upon taking multiple trials. 


\section{Average variance Extracted}

Table 2

\begin{tabular}{|l|c|}
\hline \multicolumn{1}{|c|}{ Constructs } & Average Variance Extracted \\
\hline Intrinsic Motivation & .571 \\
\hline Extrinsic Motivation & .63 \\
\hline Availability & .512 \\
\hline Collaboration & .522 \\
\hline Notification & .589 \\
\hline Adoption Intention towards & .66 \\
Cloudbased Learning systems & \\
\hline
\end{tabular}

The Average Variance Extracted are above .5 which confirms the validity of the model

\section{Regression Analysis}

Table 3

\begin{tabular}{|c|c|c|c|c|}
\hline \multicolumn{5}{|c|}{ Model Summary } \\
\hline Model & R & R Square & $\begin{array}{c}\text { Adjusted R } \\
\text { Square }\end{array}$ & $\begin{array}{l}\text { Std. Error of } \\
\text { the Estimate }\end{array}$ \\
\hline 1 & .74 & .72 & .701 & .512 \\
\hline
\end{tabular}

Table 4

\begin{tabular}{|c|c|c|c|c|c|}
\hline \multirow[t]{2}{*}{ Model } & \multicolumn{2}{|c|}{$\begin{array}{l}\text { Unstandardized } \\
\text { Coefficients }\end{array}$} & \multirow{2}{*}{$\begin{array}{c}\text { Standardized } \\
\text { Coefficients } \\
\text { Beta }\end{array}$} & \multirow[t]{2}{*}{$\mathbf{T}$} & \multirow[t]{2}{*}{ Sig. } \\
\hline & B & Std. Error & & & \\
\hline (Constant) & 1.203 & .102 & & 4.2 & .001 \\
\hline Intrinsic Motivation & .804 & .034 & .604 & 6.67 & .000 \\
\hline Extrinsic Motivation & 1.35 & .054 & 1.6 & 3.673 & .000 \\
\hline Availability & .742 & .076 & .737 & 2.34 & .000 \\
\hline Collaboration & .81 & .042 & .709 & 4.13 & .000 \\
\hline Notification & .734 & .55 & .727 & 8.36 & .000 \\
\hline
\end{tabular}

It is found from the regression analysis that the intrinsic motivation affects the adoption intention of cloud based online learning courses and the notification system provided by the online learning platforms encourages the learners towards the completion of the system.

Chi Square test between Income of the respondent and the Completion of Courses

Table 5

\begin{tabular}{|l|c|c|c|}
\hline & Value & df & Asymp. Sig. (2-sided) \\
\hline PCS & $1.419^{\mathrm{a}}$ & 3 & .002 \\
\hline LR & 1.371 & 3 & .001 \\
\hline LLA & .023 & 1 & .013 \\
\hline N of Valid Cases & 523 & & \\
\hline
\end{tabular}

Since the $\mathrm{p}$ value is found to be less than .05 , the null hypothesis of there is no significant association between income and completion of course is rejected .It is found that there is significant relationship between the Income and the completion of course 
Analysis of Variance between Gender and willingness towards collaborative learning

Table 6

\begin{tabular}{|l|c|c|c|c|c|}
\hline & $\begin{array}{c}\text { Sum of } \\
\text { Squares }\end{array}$ & df & Mean Square & F & Sig. \\
\hline Between Groups & .011 & 1 & .061 & .009 & .029 \\
\hline Within Groups & 314.464 & 522 & .542 & & \\
\hline Total & 314.535 & 523 & & & \\
\hline
\end{tabular}

Since the $\mathrm{p}$ value is less than .05, there is a significant difference in the willingness towards collaborative learning among the Male and Female respondents. Customizing the course based on this input encourages the online platform efficiency.

\section{FINDINGS}

- 59 percentage of the respondents belong to the Male category of gender

- 78 percentage of the respondents feel mobile phone to be the ease of access of the course

- 82 percentage of the respondents find their residence as the convenient place to access the course

- The chi square test confirms that there is significant relationship between the Income and the completion of course

- The Analysis of Variance confirms that there is a significant difference in the willingness towards collaborative learning among the Male and Female respondents

\section{CONCLUSION}

It is found that the intrinsic motivation of the learners is found to be the motivator for the learner adoption of the cloud based learning courses. The business models that created in the online learning zone must have a tool to motivate the intrinsic urge towards the enrollment for the courses. The notification systems must be periodically timed for the successful completion of the courses which enhances the word of mouth marketing among the satisfied learners.

\section{REFERENCES}

[1] Arkorful, V., \& Abaidoo, N. (2015). The role of e-learning, advantages and disadvantages of its adoption in higher education. International Journal of Instructional Technology and Distance Learning.

[2] Ghirardini, B. (2011). E-learning methodologies: A guide for designing and developing elearning courses. Food and Agriculture Organization of the United Nations (FAO). https://doi.org/I2516E/1/11.11

[3] Koohang, A., Riley, L., Smith, T., \& Schreurs, J. (2009). E-Learning and Constructivism: From Theory to Application E-Learning and E-Learning Design What is Constructivism? Elearning.

[4] Liaw, S. S. (2008). Investigating students' perceived satisfaction, behavioral intention, and effectiveness of e-learning: A case study of the Blackboard system. Computers and Education. https://doi.org/10.1016/j.compedu.2007.09.005

[5] Lin, K. M. (2011). E-Learning continuance intention: Moderating effects of user e-learning experience. Computers and Education. https://doi.org/10.1016/j.compedu.2010.09.017 
[6] Moore, D. R. (2006). E-Learning and the Science of Instruction: Proven Guidelines for Consumers and Designers of Multimedia Learning. Educational Technology Research and Development. https://doi.org/10.1007/s11423-006-8254-8

[7] Moore, J. L., Dickson-Deane, C., \& Galyen, K. (2011). E-Learning, online learning, and distance learning environments: Are they the same? Internet and Higher Education. https://doi.org/10.1016/j.iheduc.2010.10.001

[8] Paechter, M., Maier, B., \& Macher, D. (2010). Students' expectations of, and experiences in elearning: Their relation to learning achievements and course satisfaction. Computers and Education. https://doi.org/10.1016/j.compedu.2009.08.005

[9] Park, S. Y. (2009). An analysis of the technology acceptance model in understanding University students' behavioral intention to use e-Learning. Educational Technology and Society.

[10] Sangrà, A., Vlachopoulos, D., \& Cabrera, N. (2012). Building an inclusive definition of elearning: An approach to the conceptual framework. International Review of Research in Open and Distance Learning. https://doi.org/10.19173/irrodl.v13i2.1161

[11] Shalev-Shwartz, S. (2011). Online learning and online convex optimization. Foundations and Trends in Machine Learning. https://doi.org/10.1561/2200000018

[12] Shen, D., Cho, M. H., Tsai, C. L., \& Marra, R. (2013). Unpacking online learning experiences: Online learning self-efficacy and learning satisfaction. Internet and Higher Education. https://doi.org/10.1016/j.iheduc.2013.04.001

[13] Sun, P. C., Tsai, R. J., Finger, G., Chen, Y. Y., \& Yeh, D. (2008). What drives a successful eLearning? An empirical investigation of the critical factors influencing learner satisfaction. Computers and Education. https://doi.org/10.1016/j.compedu.2006.11.007

[14] Tavangarian, D., Leypold, M., Nölting, K., Röser, M., \& Voigt, D. (2004). Is e-Learning the Solution for Individual Learning?. Electronic Journal of E-Learning.

[15] Urh, M., Vukovic, G., Jereb, E., \& Pintar, R. (2015). The Model for Introduction of Gamification into E-learning in Higher Education. Procedia - Social and Behavioral Sciences. https://doi.org/10.1016/j.sbspro.2015.07.154 